\title{
A TILE FROM ROMAN VIENNA IN JOHANNESBURG ${ }^{1}$
}

\section{B Saddington (University of the Witwatersrand, Johannesburg)}

Recently Mr W.H. Grimm, who grew up in Vienna, asked me to decipher the letters on a fragment of a tile which he had found as a boy at Carnuntum. Apparently it was lying on the roadside having been thrown there by a farmer ploughing an adjacent field.

The tile, now some 7 by $8 \mathrm{~cm}$ large, has the letters XIIII G stamped on it but the stamp is incomplete. Originally it must have had the letters LEG before the numeral, i.e., LEG XIIII G. This was an abbreviation for LEG(io) XIV G(emina), the Fourteenth Twin (or composite) Legion. ${ }^{2}$

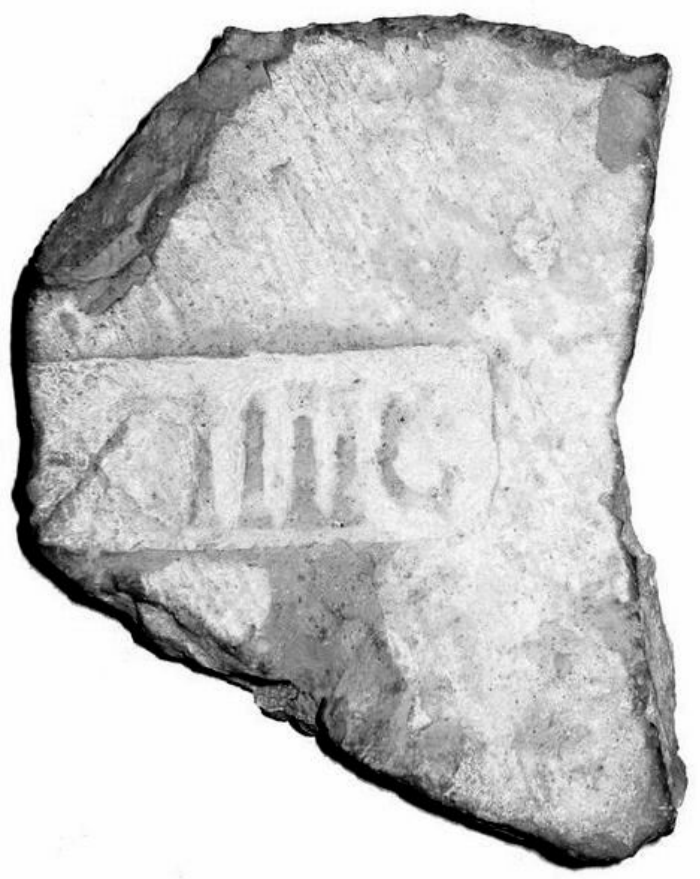

Fig. 1 The Carnuntum tile

It was the custom of legions and other units in the Roman army (and navy) to stamp the tiles which they manufactured for roofing the buildings in their fortresses. ${ }^{3}$ They are often discovered: some 2500 are known from Vindobona (Roman Vienna) alone. ${ }^{4}$

\footnotetext{
1 I wish to thank Dr. and Mrs. Zabehlicky and Prof. E. Weber of Vienna for kindly discussing the tile with me.

2 The type is recorded in Neumann 1973:87ff.

3 On Roman tileries cf. Hanel 2001: 212; $165 \mathrm{ff}$.

$4 \quad$ Gugl et al. 2005: 971ff.
} 
The Romans had long had a presence on the eastern coast of the Adriatic which they called Illyricum. Julius Caesar had been appointed governor of Illyricum in 59 B.C., but in the end campaigned mainly in Gaul. It was left to Augustus to extend Roman control into the interior of the Balkan area. Claudius first placed legions on the Danube itself. The first legion to be stationed at Carnuntum was XV Apollinaris, there from c. A.D. 40-62. It was succeeded by X Gemina till 68, when XV Apollinaris returned. But it left again in 114, when XIV Gemina replaced it, to remain there until the end of the empire. By that date the large area of Illyricum had been divided into two provinces, Dalmatia in the south and Pannonia in the north: Carnuntum was in Pannonia. ${ }^{5}$

There were about some 30 legions in the Roman army. A legion comprised 5 to 6000 men. They were numbered, but not in sequence. They acquired titles, like the II Augusta (which was stationed in Britain), named after the emperor. XV Apollinaris may have derived its name from Apollo, the god to whom Octavian, the future emperor Augustus, ascribed his victory over Antony and Cleopatra at Actium in 31 B.C. Gemina, literally 'twin,' means a single legion amalgamated from two or more others which had suffered heavy loss in battle. XIV Gemina had served in Illyricum under Augustus before being transferred to Mainz (Moguntiacum in Latin) in Germany, where it stayed until Claudius transferred it to Britain for his invasion of the island in AD 43. Possibly there it acquired the sobriquet of Martia Victrix, 'Mars' Victorious' Legion for its part in repressing the revolt of Boudica (Tennyson's Boadicea) under Nero. It then went to Germany for a second time before ending up in Pannonia.

Carnuntum is well worth a visit. ${ }^{6}$ It lies in attractive countryside with well preserved archaeological remains. It is situated next to the village of Bad Deutsch-Altenburg on the Danube some $40 \mathrm{~km}$ down-stream from Vienna. A civilian town grew up near to it, at modern Petronell. The remains of two amphitheatres, baths, temples and other structures are still visible. The most notable monument is the Heidentor, or the Heathens' Gate, as it came to be known in the Middle Ages, an impressive tetrapylon or four-columned arch, two of whose pillars remain (Fig. 2).

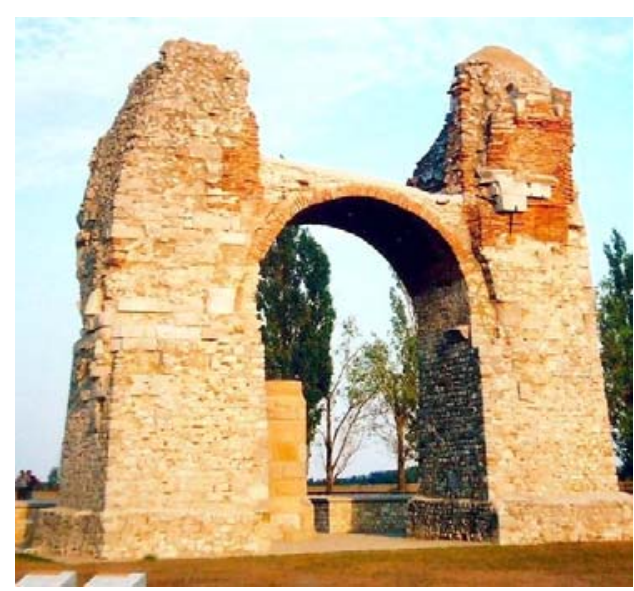

Fig. 2 The tetrapylon at Carnuntum

\footnotetext{
$5 \quad$ For the numbers and the titles of the legions cf. Keppie 1984: 132ff.; 136ff.; for their disposition Ritterling RE XII (1924-5) 1211ff.

6 For Carnuntum cf. Swoboda 1964; Jobst 1983.
} 
There is a fine museum, preserving among other exhibits statues of the gods worshipped by the army and soldiers' tombstones (Figs. 3 - 4). Two may be illustrated, the first (AE 1929, 127) the gravestone of a legionary.

Fig. 3. Tombstone of a soldier in XIV Gemina

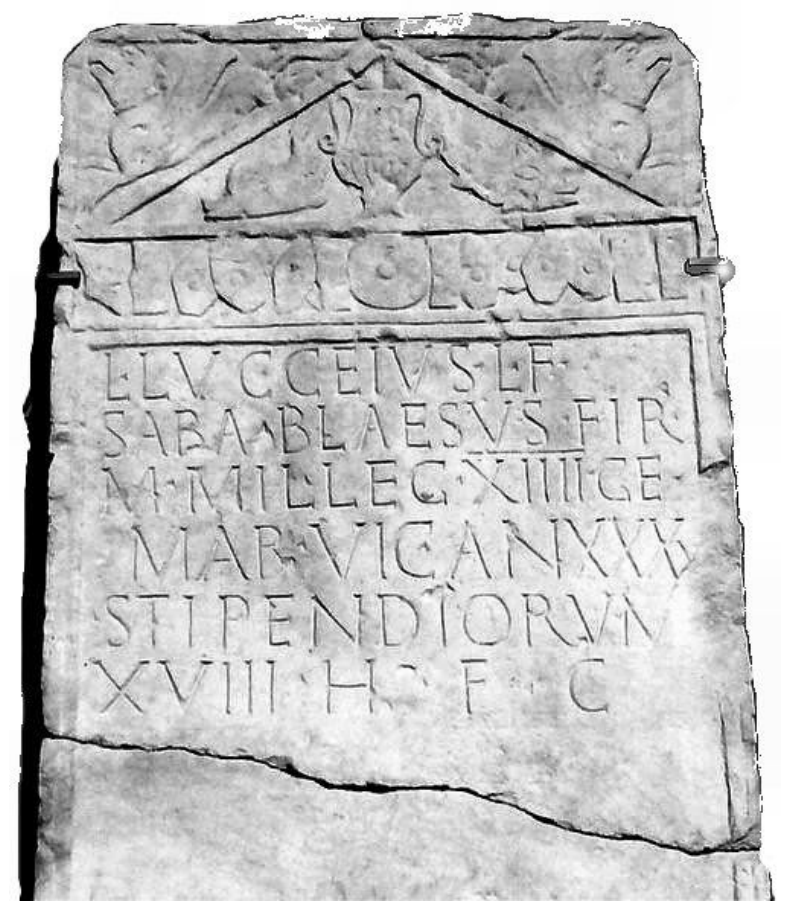

L (VCIVS) LVCCEIVS L (VCII) F (ILIVS)

SABA (TINA TR.) BLAESVS FIR-

M (O) MIL (ES) LEG (IONIS) XIIII GE (MINAE)

MAR (TIAE) VIC (TRICIS) AN (NORVM) XXXV

STIPENDIORVM

XVIII H (ERES) F (ACIENDVM) C (VRAVIT)

\section{Lucius Lucceius Blaesus, the son of Lucius, of the Sabatina voting constituency, from Fermo (in Italy), soldier of the legion XIV Twin Martial Victorious, 35 years old, 18 years of service. \\ His heir, son to the making (of this).}

The second is reasonably connected with a verse in the Bible referring to an 'Italian cohort' in which the centurion Cornelius served (Acts 10,1). An optio (second-incommand to a centurion) in a Coh II Italica is buried in Carnuntum (Fig. 4). He came from Philadelphia (now Amman), i.e., from the Decapolis near Judaea, as part of a detachment of archers in the Syrian army (ILS 9168). His unit could have been 
transferred from the East to the Danube during the civil wars of the 'Year of the Four Emperors' (A.D. 69).

Fig. 4.

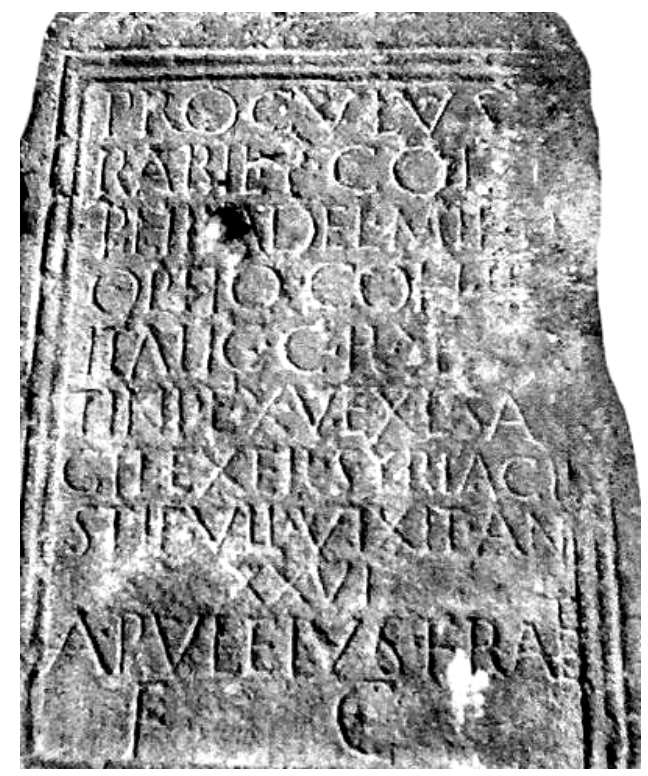

PROCVLVS / RABIL (I)

F (ILVS) COL (LINA TR.)

PHILADEL (PHIA) MIL (ES)

OPTIO COH. II / ITALIC (AE)

C (IVIVM) R (OMANORVM)

7 (=CENTVRIA) FA [VS] / TINI

EX VEXILI (LATIONE)

SAGIT (TARIORVM)

EXER (CITVS) SYRIACI

STIP (ENDIORVM) VII VIXIT

AN (NOS) XXVI

APVLEIVS FRAT (ER)

F (ACIENDVM) C (VRAVIT).

Proculus, the son of Rabilus, of the Colline voting constituency, from Amman, a junior officer in the Cohort II Italica of Roman Citizens, in the century of Faustinus from the detachment of archers of the Syrian army. He served 7 years and was 26 years old. His brother Apuleius saw the making (of this).

The emperor Marcus Aurelius used Carnuntum as his headquarters in his wars against the Germanic tribes north of the Danube, writing part of his Stoic autobiography, the 'Meditations', there. At the end of the 2nd century the then governor of Pannonia based at Carnuntum, a man from Lepcis Magna (now in Libya) staged a successful revolt for the throne. His name was Septimius Severus, the first African to become emperor at Rome.

\section{BIBLIOGRAPHY}

Neumann, A 1973. Ziegel aus Vindobona. RLÖ XXVII.

Hanel, N 2001. In: T Fischer (ed) Die römischen Provinzen. Stuttgart: Theiss Verlag. Gugl, C et al. 2005. Archaeometrical and Archaeological Research on Stamped Tiles from the Carnuntum and Vindobona Region (Austria), Limes XIX Pécs 2003.

Keppie, L 1984. The Making of the Roman Army. London: Batsford.

Ritterling RE XII (1924-5).

Swoboda, E 1964. Carnuntum: seine Geshichte und seine Denkmäler. Graz-Köln: Böhlau Verlag.

Jobst, W 1983. Provinz Haupstadt Carnuntum. Wien: Österreichische Bundesverlag. 